\title{
THE PRAIRIE GOOSEFOOTS
}

DIANA BIZECKI ROBSON, The Manitoba Museum, 190 Rupert Avenue, Winnipeg, MB R3B 0N2, E-mail: <drobson@manitobamuseum.ca>

\section{Introduction}

In this article I will: (1) discuss the taxonomy, habitat, distribution, status and economic impact of the goosefoot (Chenopodium) genus, (2) describe the general characteristics of the goosefoots, and (3) present a taxonomic treatment of the genus consisting of a dichotomous key and descriptions of those species found in the Canadian prairies. All of the species described also occur in the United States.

The common name goosefoot refers to both the family Chenopodiaceae and the genus Chenopodium. In this paper, it will refer to the latter. The common name goosefoot is a literal translation of the scientific name based on the Greek words chen meaning goose and pous meaning foot. This name refers to the leaf shape of some species in this group. The goosefoots are often overlooked due to their small, inconspicuous flowers. In North America, the goosefoot genus consists of only 34 species. In the prairie provinces of Canada, there are 20 species in total, six of which are introduced from Eurasia. The genus has been recently reviewed taxonomically by the Flora of North America ${ }^{24}$ committee and there are now twice as many species in the prairie provinces as reported in earlier floras ${ }^{14,19}$ due to recent discoveries and taxonomic "splitting" of species like Narrow-leaved Goosefoot (C. leptophyllum). Identification of goosefoot species can be difficult due to the variable nature of the leaves, and close examination of the fruits is often needed for confirmation.

\section{Habitat and Distribution}

Goosefoot species occur mainly in dry, saline and disturbed habitats. They have a number of adaptations that make this possible. Succulent leaves store water for use in times of drought and narrow leaves have less surface area from which water can evaporate, both of which increase water use efficiency. ${ }^{3,13}$ An annual habit means that goosefoot seeds can remain dormant until conditions are moist enough to support their growth. Many goosefoot species also are tolerant of saline conditions. Surviving in saline soils requires that the plant maintain a high enough concentration of salts that saline water will continue to flow into the roots. However, as salts can be harmful to plant cells, some method of dealing with the salts is needed. Many goosefoot species store salts in special inflated hairs, called salt glands or bladders. ${ }^{3}$ The presence of these glands gives goosefoots their "scurfy" or "mealy" appearance. Succulence also contributes to salt tolerance because the stored water dilutes the salts, making them less harmful. ${ }^{3,13}$

Most goosefoot species in the prairie provinces occur in the Prairie ecozone. ${ }^{1}$ The species with narrow leaves are typically found on dry, sandy soils in the plains while those with wider leaves are generally found in moister conditions at the edges of woodlands 


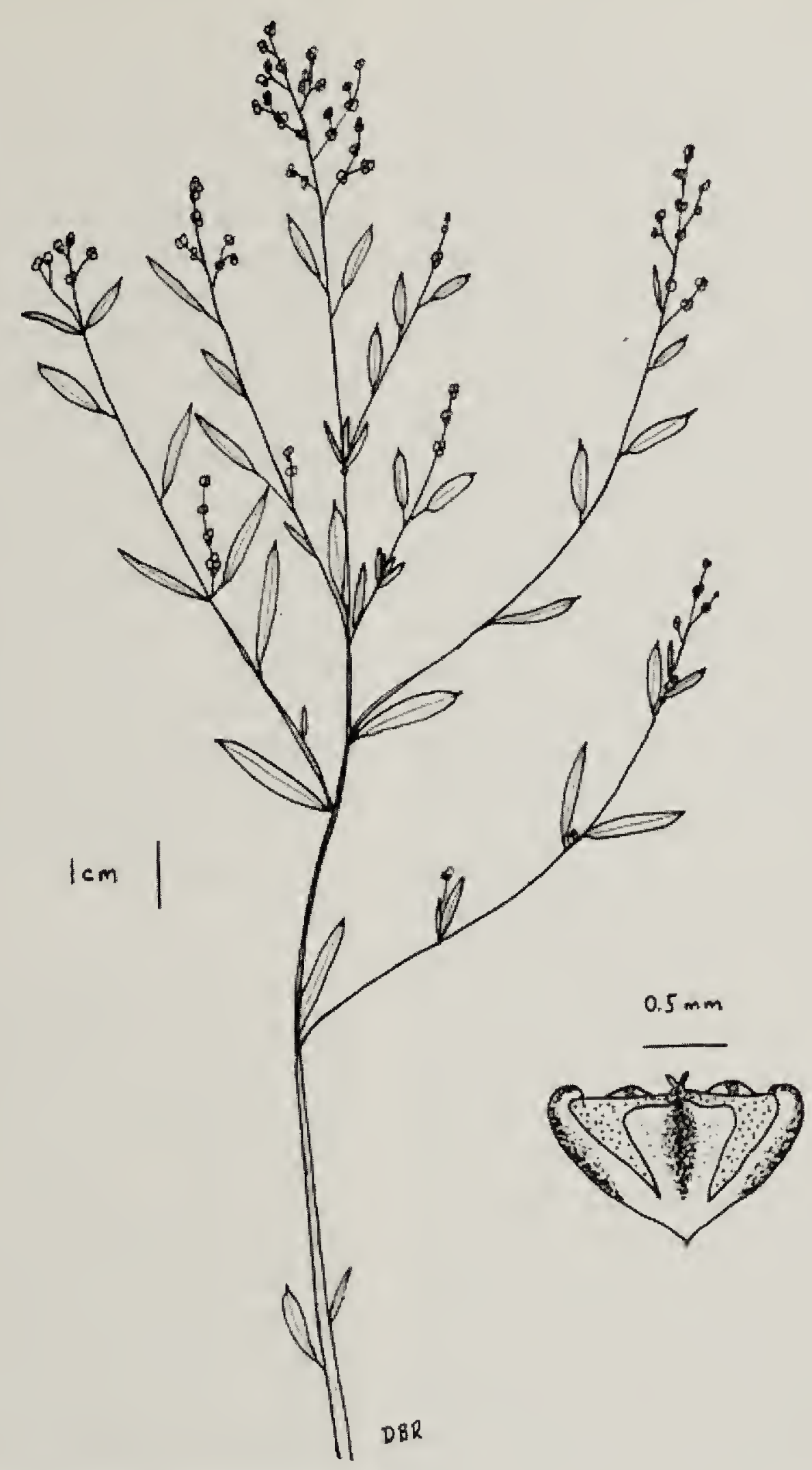

Figure 1. Chenopodium subglabrum.

D.B. Robson.

or among bushes. Saline (C. cultivated fields and gardens. ${ }^{24}$ glaucum) and Red Goosefoot (C. Lamb's-quarters ( $C$. album), the most rubrum) are commonly found around common introduced goosefoot saline wetlands. ${ }^{4}$ The native species that are fairly common in the Boreal Plains ecozone are Strawberry Blight (C. capitatum), Berlandier's Goosefoot (C. berlandieri) and Maple-leaf Goosefoot (C. simplex). 1,4 Introduced species are typically found along roadsides, disturbed areas, and in species, is found in the Prairie, and Boreal Plain and Shield ecozones as far north as Churchill in Manitoba, Lake Athabasca in Saskatchewan and Peace River in Alberta. ${ }^{23}$

Status of the Goosefoots in Canada Of the 14 native species found in the 66 (2) June 2008 
prairies, seven are relatively rare. Smooth Goosefoot (C. subglabrum) is considered nationally threatened and is protected under the Species at Risk Act (Figure 1). ${ }^{17}$ Smooth Goosefoot is restricted to sand dunes and uncultivated sand plains in the prairie provinces. ${ }^{17}$ Two other goosefoot species are considered nationally rare: Narrowleaf Goosefoot ( $C$. leptophyllum) and Dakota Stinking Goosefoot (C. watsonii). ${ }^{2}$ Narrowleaf Goosefoot is found on sandy soils in all three prairie provinces while Dakota Stinking Goosefoot has been found on heavily eroded, clayey soils along river valleys in southern Alberta and Saskatchewan. 12, 16 Dark Goosefoot (C. atrovirens) and Mealy Goosefoot (C. incanum) are considered provincially rare in Alberta and Saskatchewan. ${ }^{10,12}$ Hians' Goosefoot (C. hians) is rare in Saskatchewan with only one confirmed specimen ever being found. ${ }^{10}$ Arid Goosefoot ( $C$. dessicatum) is considered rare in Alberta and uncommon in Saskatchewan. ${ }^{10,12}$ In addition to growing in relatively uncommon habitats, the rarity of these species is due in part to their annual habit; they appear to germinate erratically and are thus temporally rare. ${ }^{16,17}$ It is possible that these species are adapted to the soil disturbances made by herds of migratory Bison, as well as rodents like the Black-tailed Prairie Dog. ${ }^{16}$ In recent times, rare goosefoot plants have been found in areas of native grassland that have been heavily grazed and trampled by cattle, further lending support to this hypothesis.

Four of the native species are considered to be weeds of gardens, waste areas, roadsides and edges of cultivated fields, namely Berlandier's Goosefoot, Strawberry Blight, Maple-leaf Goosefoot and Saline Goosefoot. ${ }^{18}$ Berlandier's Goosefoot is of particular concern as it is an intermediate host to the crop. pest, beet leafhopper. ${ }^{18}$

Six species of goosefoot are introduced from Eurasia. One of these species, Lamb's-quarters, is a common agricultural weed although it is also eaten as a potherb in many countries. ${ }^{18}$ Lamb's-quarters is the alternate host for a number of viral crop diseases. ${ }^{18}$ The potherb Good King Henry ( $C$. bonushenricus) is sometimes cultivated in prairie gardens and occasionally escapes but has not become a serious weed. ${ }^{4}$ The remaining four introduced species (C. foliosum, C. murale, $C$. polyspermum var. acutifolium and $C$. strictum) are relatively uncommon weeds moving north from the United States, but they have the potential to become more troublesome, especially if climate warming makes conditions in the prairies more suitable for their growth. ${ }^{9}$

The rarity of many goosefoot species as well as their potential to become crop weeds in a changing climate makes collection and identification of plants in this genus extremely important. Unusual specimens observed are therefore worth collecting and donating to herbaria to better determine the distribution and frequency of these species.

\section{Economic Impact of Goosefoots}

The goosefoot family contains many of the species that we consider to be weeds including Russian Pigweed (Axyris amaranthoides L.), Russianthistle (Salsola tragus L.) and Summer Cypress (Kochia scoparia (L.) Schrad.). However, it also contains several highly nutritious species such as Beet and Swiss Chard (Beta vulgaris L.), Spinach (Spinacia oleracea L.), and the wild forage plant Winterfat (Krascheninnikovia lanata (Pursh) Meeuse \& Smit). 
The goosefoot genus has several species that are grown as crop plants. Quinoa (Chenopodium quinoa Willd.) was originally cultivated by the Incas of Peru over 5,000 years ago. ${ }^{7}$ Quinoa fell out of favour as modern crop plants spread, but is still in cultivation today as it is relatively drought, frost and salttolerant making it an excellent crop plant in adverse growing conditions. ${ }^{7}$, 11 Quinoa is very nutritious due to the high protein content. ${ }^{23}$ In fact, it is one of the only foods with all nine essential amino acids, making it nutritionally valuable for vegetarians in particular. 23 Raw Quinoa must first be rinsed to remove the bitter and mildly toxic saponins from the seed. ${ }^{7}$ Due to the lack of the protein gluten, Quinoa can be eaten by people with a gluten (i.e. wheat) allergy. The seeds can be cooked like rice or couscous, or ground up and used as flour.

Other important pseudograins in this genus include Kaniwa ( $C$. pallidicaule Aellen), which is still grown in Peru and Bolivia, and Pitseed Goosefoot or huauzontle (C. berlandieri Moq. ssp. nuttalliae (Saff.) H. D. Wilson \& Heiser), which is still grown in Mexico. ${ }^{23}$ Pitseed Goosefoot was one of the crops in the Eastern agricultural complex, a group of plants that were cultivated by First Nations in the east and midwestern part of the United States. ${ }^{8}$ Pitseed Goosefoot was grown along with Squash (Cucurbita pepo L.), Little Barley (Hordeum pusillum Nutt.), Erect Knotweed (Polygonum erectum L.), Maygrass (Phalaris caroliniana Walter), Sumpweed or Marshelder (Iva annua L.), and Sunflower (Helianthus annuus L.), starting approximately 2,000 years ago. ${ }^{20}$ About 1,100 years ago cultivation of these early crop plants was slowly abandoned in favour of a new, cold-tolerant variety of maize (Zea mays L.). ${ }^{8}$ The arrival of Europeans in the late 1400 s led to the further abandonment of these species in favour of Old World crops. Active suppression of the use of some traditional crops also occurred: the Incas considered Quinoa sacred, so Spanish conquistadors discouraged them from growing this plant as a method of cultural subjugation. ${ }^{25}$

Several species of goosefoots are grown mainly for their leaves: Lamb'squarters, known in Europe as Fat Hen; Good King Henry; Jerusalem Oak (Chenopodium botrys L.); Foetid Goosefoot or yerba del zorillo (C. graveolens Willd.); and Wormseed or epazote (C. ambrosioides L.). ${ }^{7,22,23}$ The first three plants are native to Europe and have become naturalized in many places around the world including Canada. Archaeological evidence suggests that Lamb'squarters may have been grown for its seeds during the Neolithic Age by Europeans before crops from the Middle East came to dominate the agriculture of the region. ${ }^{5,21}$ Lamb'squarters and Good King Henry have highly nutritious leaves that can be eaten raw in a salad or cooked like spinach. ${ }^{23}$ Jerusalem Oak leaves are eaten like spinach but also used as an herb. Foetid Goosefoot leaves are edible but toxic in large quantities and uncommon outside Latin America. ${ }^{22,}$ 23 Mexicans use Wormseed as an herb in a wide range of traditional dishes. ${ }^{22}$ Wormseed is also grown for its oil, which is useful for expelling intestinal worms. ${ }^{22}$ All five of these plants are rarely available commercially in North America, being grown only occasionally in home gardens.

As goosefoot plants are windpollinated, they may cause rhinitus or hay fever in sensitized people. ${ }^{6}$ Goosefoot plants typically flower in summer and fall and can produce copious quantities of pollen. Although 
all goosefoot plants can potentially cause hay fever, the species most likely to affect people is Lamb'squarters as it is widespread, abundant and present in disturbed, urban and agricultural habitats. ${ }^{6}$ People with summer and fall hay fever should avoid growing goosefoot plants like Good King Henry in their gardens, or alternatively consume the plants before they flower to prevent exposure.

Description of Chenopodium 4, 14, 15, 24 This genus contains mainly annual, but also a few perennial, herbs that are glabrous (i.e. smooth, lacking hairs or glands) or farinose (i.e. covered with small, white bladders). The stems are erect to prostrate, typically branched and unarmed. The leaves are alternate on the stem, stalked or rarely sessile, linear, oblong, lanceolate, ovate, triangular or rhombic in shape, with margins that are entire, toothed, wavy or lobed, and often farinose. The inflorescences consist of terminal or axillary. spikes or panicles of glomerules (i.e. dense, often rounded clusters of flowers). The flowers are small, greenish, with no bracts or petals, 3-5 sepals that are keeled or rounded and may be fused at the base, 5(1) stamens, 2 stigmas, and a superior ovary. The fruit is an achene or a utricle, and may be covered by the sepals at maturity. An achene is a oneseeded fruit with a firm, close-fitting pericarp (i.e. fruit wall) not easily separated from the seed, while a utricle is one-seeded fruit with a thin, bladdery, inflated pericarp that is readily separable from the seed. The pericarp is smooth or variously textured. The seeds can be vertical or horizontal (Figure 2), lens-shaped to rounded, black, brown-black or reddish brown, smooth, warty, rugose (i.e. wrinkled), punctate (i.e. pitted) or with a honeycombed texture.

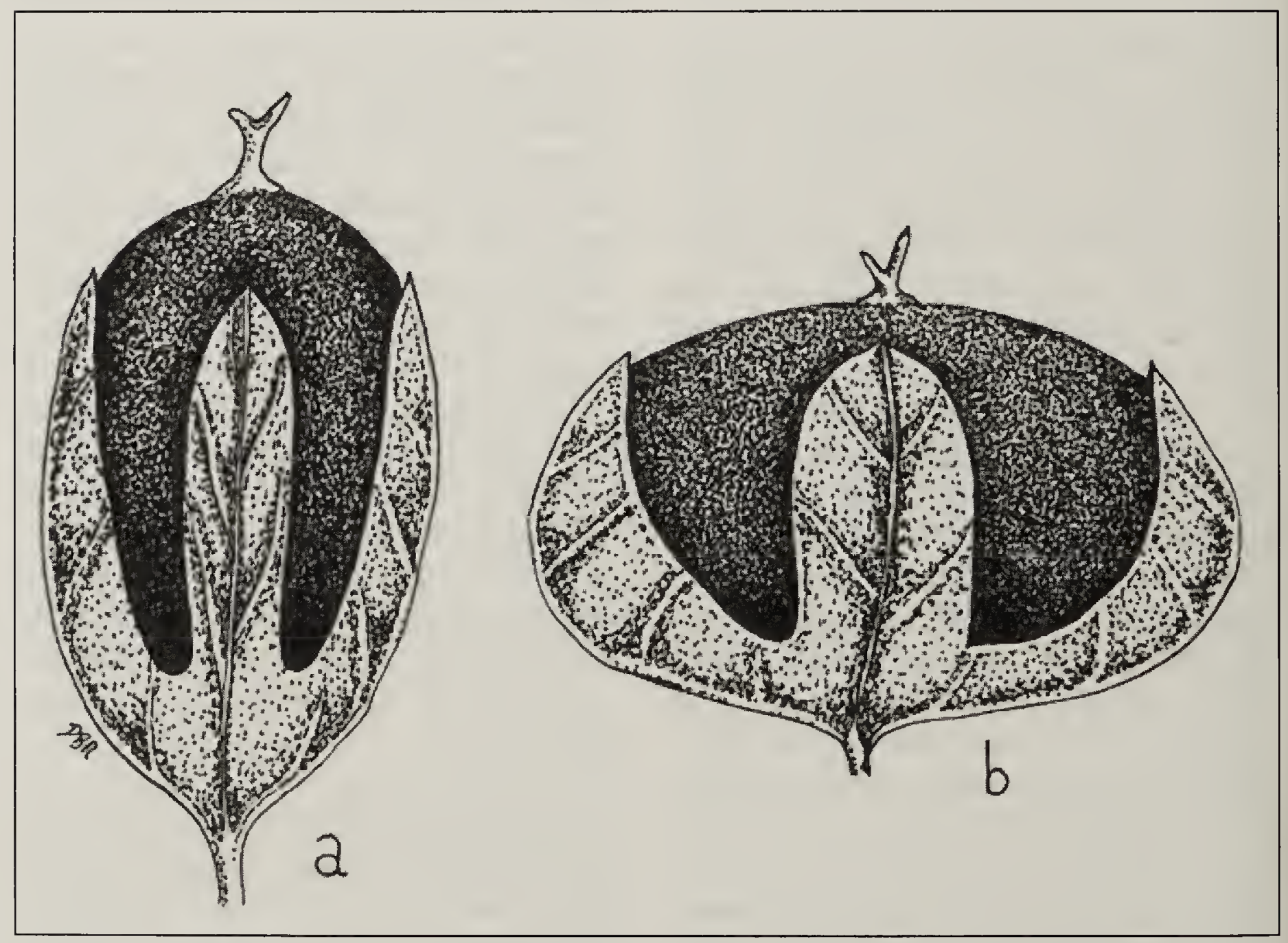

Figure 2. Vertical (a) and horizontal (b) fruits in the goosefoot genus.

D.B. Robson 
1a. Calyx fleshy, red, and globular, resembling a small strawberry 2

1b. Calyx not fleshy, red, and strawberry-like

2a. Leaf-like bracts present throughout the flower spike; flowers maturing from base upwards; 1 stamen

C. foliosum

2b. Leaf-like bracts present only in lower half of the flower spike; flowers maturing from top downwards; 3 stamens

C. capitatum

3a. Leaves mostly linear, occasionally linear-lanceolate or oblong-ovate, 2-3 times longer than wide or longer; entire or with two basal lobes 4

3b. Leaves deltoid, rhombic, oblong or ovate; to 2 times longer than wide; entire, toothed or lobed 9

4a. Leaves with 1 vein, blades linear, margins entire 5

4b. At least the lower leaves with 3 veins from the base, blades linear to lanceolate, margins may have 2 basal lobes 6

5a. Leaves glabrous to very sparsely farinose, fleshy; fruit a utricle (with a loose, inflated pericarp); seeds $1.3-1.5 \mathrm{~mm}$ in diameter C. subglabrum

5b. Leaves moderately to densely farinose, not fleshy; fruit an achene (with a close-fitting pericarp); seeds $0.9-1.2 \mathrm{~mm}$ in diameter

C. leptophyllum

6a. Sepals covering the fruit at maturity

C. dessicatum

6b. Sepals not covering the fruit at maturity

7a. Leaves 1.5-3 times longer than broad, lower surface almost glabrous; glomerules in a loose panicle-like inflorescence; pericarp smooth..... . atrovirens

7b. Leaves 3 times longer than broad, lower surface farinose; glomerules in dense spikes or panicles; pericarp smooth or warty.

8a. Fruit a utricle (with a loose, inflated pericarp); pericarp smooth; seeds rounded; lower leaves often with two prominent basal lobes or teeth C. pratericola

8b. Fruit an achene (with a close-fitting pericarp); pericarp with small warts; seeds flattened; lower leaves entire C. hians

9a. Seeds vertical, or both vertical and horizontal 10

9b. Seeds all horizontal 12

66 (2) June 2008 
10a. Plants perennial; sepals 5 ; seeds more than $1.5 \mathrm{~mm}$ in diameter; fruits are achenes (with a close-fitting pericarp)

C. bonus-henricus

10b. Plants annual; sepals 3 or 4 ; seeds less than $1.5 \mathrm{~mm}$ in diameter; fruits are utricles (with a loose, inflated pericarp)

11a. Leaves farinose, the underside white; seeds rugose-punctate.

C. glaucum

11b. Leaves glabrous, the underside not white or sparsely white, usually blackening upon drying; seeds smooth

C. rubrum

12a. Mature plants short, up to $25 \mathrm{~cm}$ high

12b. Mature plants tall, up to $50 \mathrm{~cm}$ high

13a. Plants up to $15 \mathrm{~cm}$ high when mature; fruit a whitened achene (with a close-fitting pericarp); leaves with a fishy scent when bruised

C. watsonii

13b. Plants up to $25 \mathrm{~cm}$ high when mature; fruit a utricle (with a loose, inflated pericarp); leaves lacking a fishy scent

C. incanum

14a. Flowers individually arranged in panicles; leaf blades glabrous

14b. Flowers in loose or dense glomerules; leaf blades usually farinose ... 16

15a. Leaves wavy to toothed; seeds $1.3-1.9 \mathrm{~mm}$ in diameter

C. simplex

15b. Leaves entire; seeds $0.8-1.3 \mathrm{~mm}$ in diameter.

C. polyspermum

16a. Seeds deeply honeycomb-pitted

C. berlandieri

16b. Seeds warty or smooth

17a. Leaves triangular; margins entire, lobed or toothed

17b. Leaves ovate to broadly ovate, rhombic or lanceolate; margins lobed or toothed

18a. Leaf blades toothed and sometimes with basal lobes, older leaves glabrous

C. murale

18b. Leaf blades with basal lobes but not toothed; leaf blades usually farinose C. fremontii

19a. Leaf margins tapering to an acute apex; leaf blades stalked and ovate, rhombic or lanceolate; seeds circular in outline

C. album

19b. Leaf margins roughly parallel below the obtuse apex; leaf blades sessile and lanceolate to narrowly elliptic; seeds oval in outline

C. strictum 
Descriptions of Goosefoot Species ${ }^{4,}$ $10,12,14,15,19,24$

The plants are arranged alphabetically according to their scientific names since many of the plants have more than one common name. After each scientific name there is a list of the synonyms for that species. (A synonym is a name that formerly was used for the plant.) The flowering period is noted in the descriptions; it can vary considerably depending on the geographic location and weather conditions.

\section{Chenopodium album L. - Lamb's- quarters or White Pigweed}

[C. a. ssp. dacoticum Aellen; C. a. var. fallax Aellen; C. a. var. lanceolatum (Muhl. ex Willd.) Coss. \& Germ.; C. a. var. polymorphum Aellen; $C$. amaranticolor Coste \& Reyn; C. giganteum D. Don; C. lanceolatum Muhl. ex Willd.; C. paganum auct. non Reich.; C. suecicum Murr.]

An erect to sprawling annual, 20-80 $\mathrm{cm}$ high, simple to much branched, usually with reddish striped stems. Leaves with $1-2.5 \mathrm{~cm}$ stalks, ovate, rhombic or lanceolate with an acute to subobtuse apex, usually wavymargined, farinose, $1-6 \mathrm{~cm}$ long and $0.5-4 \mathrm{~cm}$ wide. Inflorescence in terminal and axillary panicles of dense glomerules. Sepals 5, not fused, the lobes ovate, keeled and obtuse at the apex, largely covering the fruit at maturity. Fruits horizontal, smooth to bumpy utricles. Seeds black, smooth to finely rugose, circular in outline and 0.9-1.6 $\mathrm{mm}$ in diameter. JuneSeptember. An introduced, highly variable, and common weed found in waste places, roadsides, and gardens throughout the prairie provinces.

\section{Chenopodium atrovirens Rydb. -} Dark Goosefoot or Pinyon Goosefoot [C. aridum A. Nels.; C. fremontii S. Wats. var. a. (Rydb.) Fosberg; C. incognita Wahl; C. wolfii Rydb.]
An erect to semi-erect annual, 10$50 \mathrm{~cm}$ tall, usually with many ascending to arched or drooping branches. Leaves with $0.5-1.5 \mathrm{~cm}$ stalks, ovate, oblong or oval, 3-veined, obtuse to rounded at apex, rounded to cuneate at base, margins entire or rarely with two basal lobes, sparsely farinose initially becoming glabrous, $1-3 \mathrm{~cm}$ long and 0.4-2.2 cm wide. Inflorescence consists of dense glomerules in terminal and axillary paniculate spikes. Sepals 5 , not fused, with obovate lobes that are sparsely farinose and with a rounded or notched apex that does not cover the fruit at maturity. Fruits horizontal, smooth achenes or utricles. Seeds dark redbrown to black, shiny, obscurely wrinkled, lens-shaped and 0.9-1.3 $\mathrm{mm}$ in diameter. July-September. Native and rare in open disturbed sites, generally at higher elevations in Alberta and Saskatchewan.

3. Chenopodium berlandieri Moq.Tandon var. zschackei (Murr) Murr Pit-seed Goosefoot or Net-seed Lamb's-quarters

[C. acerifolium Andrz.; C. album L. var. b. (Moq.) Mack. \& Bush; C. b. ssp. z. (Murr) A. Zobel; C. b. var. farinosa (Ludwig) Aellen; C. b. var. platyphyllum (Issler) Ludwig; C. b. var. z. Murr.; C. boscianum auct. p.p. non Moq.; $C$. $z$. Murr.]

An erect to ascending annual, 10$100 \mathrm{~cm}$ high, simple to much branched and farinose. Leaves with $0.2-9 \mathrm{~cm}$ stalks, rhombic or deltate, with an acute to acuminate apex, base cuneate to truncate, margins entire, toothed and often with 2 basal lobes, farinose, $1.7-4 \mathrm{~cm}$ long and $0.5-3 \mathrm{~cm}$ wide. Inflorescence consists of glomerules in compound spikes. Sepals 5 , not fused, with ovate to deltate lobes that are farinose, often keeled and with an obtuse apex, sometimes covering the fruit at maturity. Fruits horizontal achenes or 
utricles that are honeycomb-pitted. Seeds brown to black, honeycombpitted and 1.2-1.5 $\mathrm{mm}$ in diameter. August-September. Native, widespread and common in the grasslands, parklands and boreal forests of the prairie provinces.

\section{Chenopodium bonus-henricus L. - Good King Henry, Fat-hen or Wild Spinach}

A perennial herb with erect to ascending, unbranched stems up to $75 \mathrm{~cm}$. Leaves with $1-12 \mathrm{~cm}$ stalks, triangular to hastate, apex acute, base truncate, cordate or hastate, margins entire, glabrous or slightly farinose, $4.5-10 \mathrm{~cm}$ long and $3-9 \mathrm{~cm}$ wide. Flowers in dense, bractless glomerules on terminal and axillary spikes, 5-19 cm long. Sepals 5, partly fused at base, apex obtuse, rounded or truncate, glabrous, not covering fruit at maturity. Fruits vertical and horizontal achenes. Seeds round, black, wrinkled and $1.5-2 \mathrm{~mm}$ in diameter. July-September. An introduced potherb that occasionally escapes from gardens.

5. Chenopodium capitatum (L.) Ambrosi var. capitatum - Strawberryblight, Indian-paint, Indian Ink

[Blitum capitatum L.]

An annual herb, erect or spreading, to $50 \mathrm{~cm}$ high. Leaves with $1-12 \mathrm{~cm}$ stalks, triangular or ovate, apex acute to acuminate, base cuneate, truncate or hastate, margins entire or dentate, glabrous, $3-10 \mathrm{~cm}$ long and $1-9 \mathrm{~cm}$ wide. Inflorescence consisting of spikes with 3-10 $\mathrm{mm}$ diameter glomerules, at intervals on the stem, turning red and resembling small strawberries, with leaf-like bracts only in the upper half of the spike; flowers maturing from apex to base. Sepals 3 , partly fused at base, with lanceolate to ovate lobes and an acute apex, covering fruit at maturity. Stamens 3 . Fruits horizontal, ovoid, fleshy, red achenes. Seeds rounded, black, reticulate-pitted and $0.7-1.2 \mathrm{~mm}$ in diameter. June-August. Native and common on rocky or stony soil, around bluffs and woodlands, and along roadsides throughout the prairie provinces, particularly in boreal forest.

6. Chenopodium desiccatum A. Nelson - Arid Goosefoot, Arid-land Goosefoot

[C. leptophyllum (Moq.-Tandon) Nutt. ex S. Wats. var. oblongifolium S. Wats.; C. I. auct. p.p. non (Moq.) Nutt.; C. o. (S.Wats.) Rydb.; C. pratericola auct. non Rydb.; C. p. Rydb. ssp. d. (A. Nels.) Aellen; C. p. var. o. (S.Wats.) Wahl]

A spreading to erect annual, $1-14 \mathrm{~cm}$ tall, usually branched from the base and densely farinose. Leaves with 0.3$0.4 \mathrm{~cm}$ stalks, linear to narrowly lanceolate, oblong-elliptic or ovatelanceolate, at least the lower leaves with 3 veins, somewhat fleshy, apex acuminate, base cuneate, margins entire, $1.5-2.5 \mathrm{~cm}$ long and $0.4-0.6 \mathrm{~cm}$ wide. Inflorescence consists of glomerules in terminal and axillary panicles. Sepals 5 , not fused, with obovate lobes, densely farinose and with an obtuse apex, covering the fruit at maturity. Fruits horizontal, smooth, ovoid utricles. Seeds black, wrinkled and 0.8-1.1 $\mathrm{mm}$ in diameter. JulySeptember. Native and uncommon or rare in undisturbed saline soils of Alberta and Saskatchewan.

\section{Chenopodium foliosum (Moench)} Ascherson - Leafy Goosefoot [Morocarpus foliosus Moench]

An annual herb to $60 \mathrm{~cm}$ tall, with stems either erect or spreading. Leaves with $0.5-6.5 \mathrm{~cm}$ stalks, triangular to oblong, apex acute to acuminate, base cuneate, truncate or almost hastate, margins wavy or dentate, glabrous, 2-8 cm long and 1$3.5 \mathrm{~cm}$ wide. Inflorescence consisting of spikes with 3-8 $\mathrm{mm}$ diameter 
glomerules, at intervals on the stem, turning red and resembling small strawberries, with leaf-like bracts throughout the spike. Flowers maturing from base to apex. Sepals 3 or 4 , partly fused at base, with obovate lobes and a rounded apex. Stamens usually 1 . Fruits horizontal, ovoid, smooth, dark reddish brown achenes. Seeds dark red-brown and 1-1.2 mm diameter. July-September. An introduced but uncommon weed in the grasslands of Alberta.

\section{Chenopodium fremontii S. Wats. -} Fremont's Goosefoot

[C.f. var. pringlei (Standl.) Aellen]

An annual with rather slender, erect, mealy stems, ranging from 10 to 80 $\mathrm{cm}$ tall, usually with longitudinal dark green lines. Leaves with $0.4-2.5 \mathrm{~cm}$ stalks, broadly triangular, sometimes ovate to elliptic, apex rounded to obtuse, base truncate or cuneate, margins entire or with a pair of basal lobes, farinose, $1-5 \mathrm{~cm}$ long and 1-4 $\mathrm{cm}$ wide. Inflorescence consisting of open, interrupted, spikes of small glomerules. Sepals 5, not fused, with ovate lobes, somewhat farinose and with an obtuse apex, covering the fruit at maturity. Fruits horizontal, ovoid, warty to smooth utricles. Seeds reddish brown to black, smooth and $1-1.3 \mathrm{~mm}$ in diameter. July-September. Native and common in moist areas among bushes and bluffs, mainly in southern Alberta and Saskatchewan.

9. Chenopodium glaucum L. var. salinum (Standl.) B. Boivin - Saline or Oak-leaf Goosefoot

[C. g. L. ssp. s. (Standl.) Aellen; C. g. var. pulchrum Aellen; C. s. Standl.]

An erect to prostrate plant, $10-40 \mathrm{~cm}$ tall with a rather fleshy, often reddish stem. Leaves with stalks to $1 \mathrm{~cm}$, lanceolate to oval or oblong, sinuately toothed or lobed, resembling small oak leaves, farinose and whitish underneath, $0.5-4 \mathrm{~cm}$ long, $0.3-1.5 \mathrm{~cm}$ wide. Inflorescence consisting of glomerules in terminal or lateral spikes subtended by leaf-like bracts. Sepals 3 or 4 , not fused, with obovate to oblong lobes that cover the fruit at maturity. Fruits horizontal and occasionally vertical, ovoid, smooth utricles. Seeds ovoid to round, dull reddish brown, rugose-punctate and $0.6-1.1 \mathrm{~mm}$ in diameter. AugustOctober. Native and common in moist, saline locations or roadsides; throughout prairies and parklands of all three prairie provinces.

\section{Chenopodium hians Standl. - Hian's or Gaping Goosefoot}

[C. incognitum auct. p.p. non Wahl]

An erect annual, $10-45 \mathrm{~cm}$ tall, simple or with a few copiously and coarsely farinose branches. Leaves with $0.2-0.7 \mathrm{~cm}$ stalks, elliptic-oblong or narrowly lanceolate, at least the lower leaves 3-veined, apex acute to rounded, base cuneate, margins entire, green and glabrous above, densely and coarsely white farinose beneath, 1.0-2.5 cm long and 0.3-0.6 $\mathrm{cm}$ wide, petioles stout and up to half as long as blade. Inflorescence consisting of dense clusters in lateral spikes or narrow panicles. Sepals 5 , not fused, with elliptic, oblong or narrowly ovate lobes that are slightly keeled, densely farinose and with a rounded apex, spreading from the fruit at maturity. Fruits horizontal achenes with small warts. Seeds lens-shaped, black, wrinkled and 1-1.4 $\mathrm{mm}$ in diameter. July-September. Native and rare in dry, sandy grasslands of southwest Saskatchewan.

\section{Chenopodium incanum (S. Wats.)}

A. Heller var. incanum - Mealy Goosefoot

[C. fremontii S. Wats. var. i. S. Wats.]

An erect to spreading, densely branched annual, farinose, ranging from 6 to $15 \mathrm{~cm}$ tall. Leaves with stalks to $1 \mathrm{~cm}$, ovate to triangular, apex acute, 
base cuneate to nearly truncate, margins toothed and usually with a pair of basal teeth, farinose, $1-1.5 \mathrm{~cm}$ long and 0.5-1.6 cm wide. Inflorescence glomerules crowded in terminal and lateral panicles. Sepals 5 , not fused, with ovate lobes, somewhat farinose and with an acute to obtuse apex, covering the fruit at maturity. Fruits horizontal, ovoid, smooth utricles. Seeds black and wrinkled, with a narrow rim and 0.9$1.1 \mathrm{~mm}$ in diameter. July-August. Native and uncommon or rare in sandy soils and hillsides in southeast Alberta and southwest Saskatchewan.

\section{Chenopodium leptophyllum} (Moq.-Tan) Nutt. ex S. Wats. Narrowleaf Goosefoot

[C. album L. var. I. Moq.]

An erect annual, $10-40 \mathrm{~cm}$ tall, usually branching from the base with a somewhat farinose stem. Leaves with stalks to $0.5 \mathrm{~cm}$, the blades linear, 1-veined, $0.7-2.6 \mathrm{~cm}$ long, $0.1-0.3 \mathrm{~cm}$ wide, somewhat fleshy, base cuneate, margins entire, apex obtuse, farinose above and densely farinose below. Inflorescence consists of dense glomerules in terminal and axillary panicles. Sepals 5 , rarely 4 , not fused, with lanceolate to elliptic lobes that are strongly keeled, densely farinose and with an obtuse to rounded apex, covering the fruit at maturity. Fruits horizontal, ovoid, smooth achenes. Seeds black, finely wrinkled and 0.9 $1.1 \mathrm{~mm}$ in diameter. July-September. Native and rare in sand dunes and sandy disturbed grasslands in all three prairie provinces.

\section{Chenopodium murale L. -} Sowbane or Nettle-leaved Goosefoot

An erect, branched, glabrous annual to $60 \mathrm{~cm}$ high. Leaves with $1-2.5 \mathrm{~cm}$ stalks, triangular, ovate or rhombic, apex acute to acuminate, base cuneate to rounded, margins irregularly toothed or lobed, mature leaves glabrous, 0.8-
$4 \mathrm{~cm}$ long and 0.4-3 cm wide. Inflorescence glomerules in terminal and lateral panicles that lack bracts. Sepals 5 , not fused, with ovate lobes that cover the fruit at maturity. Fruits horizontal, depressed ovoid, warty or smooth achenes. Seeds lens-shaped, round, black, smooth to wrinkled and $1-1.5 \mathrm{~mm}$ in diameter. August-October. An introduced but uncommon weed found in southern Alberta and Saskatchewan.

\section{Chenopodium polyspermum L.} var. acutifolium Smith - Many Seeded Goosefoot

[C. acutifolium Smith]

An erect, branched, glabrous annual to $1-\mathrm{m}$ high. Leaves with stalks to 1.7 $\mathrm{cm}$, ovate-elliptic or oblong, apex obtuse to rounded, base rounded to cuneate, entire or with a slight tooth above the base, glabrous, becoming red at maturity, $1.5-4 \mathrm{~cm}$ long and 0.4$2.5 \mathrm{~cm}$ wide. Inflorescence sparse with many axillary cymes. Sepals 5 , with oblong to elliptic lobes that do not cover the fruit at maturity. Fruits horizontal, depressed ovoid, smooth utricles. Seeds brown-black, dull and $0.8-1.3 \mathrm{~mm}$ in diameter. June-July. An introduced but uncommon weed in east-central Saskatchewan.

\section{Chenopodium pratericola Rydb. - Desert Goosefoot}

[C. albescens Small; C. desiccatum auct. non A. Nels.; C. d. A. Nels. var. leptophylloides (Murr) Wahl; C. p. var. I. (Murr) Aellen; C. leptophyllum auct. non (Moq.) Nutt.]

An erect annual, $20-80 \mathrm{~cm}$ tall, simple or with a few branches above and farinose. Leaves with $0.4-1 \mathrm{~cm}$ stalks, linear to narrowly lanceolate or oblong-elliptic, at least the lower leaves with 3 veins, apex acute, base cuneate, margins entire, often with a pair of lobes or teeth near the base, somewhat fleshy, sparsely to densely farinose, $1.5-4.2 \mathrm{~cm}$ long and $0.4-1 \mathrm{~cm}$ 
wide. Inflorescence consisting of axillary and terminal panicles. Sepals 5 , rarely 4 , not fused, with oblong to ovate lobes that are strongly keeled, densely farinose and with an obtuse, rounded or notched apex, spreading from the fruit at maturity. Fruits horizontal, ovoid, smooth utricles. Seeds round, black, wrinkled and 0.9$1.3 \mathrm{~mm}$ in diameter. July-August. A common native plant occurring on dry, sandy soils, slough margins and alkaline areas in prairies and parklands.

\section{Chenopodium rubrum L. - Red Goosefoot or Coast-blight}

[C. humile Hook.; C. rubrum L. ssp. $h$. (Hook.) Aellen]

An erect or prostrate plant to $75 \mathrm{~cm}$ high, with many ascending, glabrous branches. Leaves with stalks to 0.5 $\mathrm{cm}$, triangular to rhombic, apex obtuse to acute, base cuneate, coarsely toothed or entire, glabrous, thick, dark green but usually blackening upon drying, 1-9 cm long and 1-6 cm wide. Glomerules $2-5 \mathrm{~mm}$ in diameter in leafy axillary spikes. Sepals 3 or 4 , fused only at the base, with lanceolate to elliptic lobes that cover the fruit at maturity. Fruits vertical and occasionally horizontal, ovoid utricles with reticulate-punctate surfaces. Seeds, ovoid, smooth, dull reddish brown when ripe and $0.6-1.0 \mathrm{~mm}$ in diameter. August to October. A common native plant in saline, moist soil around sloughs and lakes, throughout the prairie provinces.

Two varieties are found in the prairies and these can be distinguished by using the following key:

1a. Stems erect or ascending; leaf margins deeply toothed; vertical seeds 0.6-0.8 $\mathrm{mm}$ wide. .var. rubrum $L$.

1b. Stems prostrate or spreading; leaf margins entire or shallowly toothed; vertical seeds 0.8-1 $\mathrm{mm}$ wide ..var. humile (Hook.) S. Wats.

\section{Chenopodium simplex (Torr.) Raf.} - Maple-leaf or Big-seed Goosefoot

[C. gigantospermum Aellen; $C$. hybridum auct. non L.; C. $h$. ssp. g. (Aellen) Hulten; C. $h$. var. g. (Aellen) Rouleau; C. $h$. var. simplex Torr.]

An erect, branched, glabrous annual, (30-) 50-120 cm high. Leaves with stalks to $0.5 \mathrm{~cm}$, ovate to triangular, apex acute, base cordate to truncate, usually wavy or with 2-4 large sharp-pointed lobes on either margin, glabrous, $3.5-15 \mathrm{~cm}$ long and $2-9 \mathrm{~cm}$ wide. Inflorescence of individually arranged flowers in interrupted panicles. Sepals 5, fused at the base, with lanceolate to ovate lobes that do not cover the fruit at maturity. Fruits horizontal, depressed ovoid, smooth achenes. Seeds lens-shaped, black and $1.3-1.9 \mathrm{~mm}$ in diameter. JulyOctober. A fairly common native plant found in shady wooded places or disturbed areas throughout the prairie provinces.

\section{Chenopodium strictum Roth - Late-flowering Goosefoot or Upright Lamb's-Quarters}

[C. album L. var. striatum (Kras.) Kartesz; C. glaucophyllum Aellen; C. strictum Roth ssp. g. (Aellen) Aellen; C. s. Roth var. g. (Aellen) Wahl]

An erect, branched, annual, 45-100 $\mathrm{cm}$ tall, glabrous to sparsely farinose. Leaves sessile, ovate-lanceolate to oblong-ovate, apex obtuse, base cuneate, margins finely toothed, farinose, $1.7-3.6 \mathrm{~cm}$ long and $1-3 \mathrm{~cm}$ wide. Inflorescence glomerules rounded and in terminal spikes. Sepals 5, not fused, farinose, the lobes ovate, slightly keeled and rounded at the apex, not covering the fruit at maturity. Fruits horizontal, depressed, ovoid, smooth achenes. Seeds black, smooth, oval in outline and 0.9-1.5 mm in diameter. August to October. An 
introduced but uncommon weed in the southern grasslands of Saskatchewan and Manitoba.

19. Chenopodium subglabrum (S. Wats.) A. Nels. - Smooth Goosefoot [C. leptophyllum auct. non (Moq.) Nutt. ex S. Wats.; C. I. (Moq.-Tan.) Nutt. ex S. Wats. var. s. S. Wats.]

An erect, branched annual, 10-55 $\mathrm{cm}$ high. Leaves with stalks to $1 \mathrm{~cm}$, linear, 1-veined, apex acute to acuminate, base cuneate, margins entire, somewhat fleshy, glabrous or very sparsely farinose, $1-3 \mathrm{~cm}$, long and 0.1-0.2 cm wide. Inflorescence consists of small widely-spaced clusters in terminal and axillary panicles. Sepals 5, partly fused at base, sparsely farinose with ovate lobes that are obtuse or rounded at the apex, sparsely farinose and largely cover the fruit at maturity. Fruits horizontal, smooth achenes. Seeds lens-shaped with a narrow rim black, smooth, shiny and 1.3-1.6 $\mathrm{mm}$ in diameter. July-September. Native and rare on sand dunes and sand plains in Alberta, Saskatchewan and Manitoba.

\section{Chenopodium watsonii A. Nels. - Watson's or Dakota Stinking Goosefoot}

[C. dacoticum Standl.; C. glabrescens (Aellen) Wahl.; C. olidum S. Wats.]

An annual 2-15 cm tall, with erect, ascending or decumbent, farinose, angular stems that are much branched. Leaves with $0.4-1.4 \mathrm{~cm}$ stalks, ovate, rounded triangular or rhombic, apex rounded to obtuse or acute, base rounded, broadly cuneate or nearly truncate, margins entire or with a pair of basal teeth, densely farinose, with a fishy scent when bruised, 1-2.6 cm long and 0.5-2.9 cm wide. Inflorescence consists of glomerules in paniculate spikes. Sepals 5 , partly fused at the base, keeled, farinose and ovate with acute to obtuse apices that cover the fruit at maturity. Fruits horizontal achenes that are whitened and honeycombed. Seeds whitened and coarsely honeycombed, subglobose and 0.9$1.3 \mathrm{~mm}$ in diameter. July-September. Native and rare in badlands, river valleys, and disturbed native prairie in Alberta and Saskatchewan.

\section{Acknowledgements}

Financial support for this research was received from The Manitoba Museum Foundation Inc. Special thanks to Jackie Krindle for helping prepare the taxonomic key and reviewing the paper, and to Tracey Wright and Kevin Szwaluk for testing the key. Specimen loans were graciously supplied by the W.P. Fraser Herbarium (SASK) at the University of Saskatchewan, University of Manitoba (WIN), University of Winnipeg (UWPG) and the Department of Agriculture Herbarium (DAO).

1. ACTON, D.F., G.A. PADBURY, and C.T. STUSHNOFF. 1998. The ecoregions of Saskatchewan. Canadian Plains Research Center, University of Regina, Saskatoon, SK.

2. ARGUS, G.W., and K.M. PRYER. 1990. Rare vascular plants in Canada. Canadian Museum of Nature, Ottawa, ON.

3. BARBOUR, M.G., J.H. BURK, and W.D. PITTS. 1987. Terrestrial Plant Ecology. Benjamin/ Cummings Publishing Co., Don Mills, ON.

4. BASSETT, I.J., and C.W. CROMPTON. 1982. The genus Chenopodium in Canada. Canadian Journal of Botany 60:585-610.

5. BOGAARD, A. The nature of early farming in Central and South-east Europe. Documenta Praehistorica XXXI: 49-58.

6. CROMPTON, C.W. 1990. The distribution and attributes of selected weeds as hayfever plants. Aerobiologia 6:128-135.

7. D'AMICO, S. 1996. The visual food encyclopedia. Quebec/Amerique International, Montreal, QC. 
8. DIAMOND, J. 1999. Guns, Germs and Steel. W.W. Norton \& Co., New York, NY.

9. DUKES, J.S., and H.A. MOONEY. 1999. Does global change increase the success of biological invaders? Trends in Ecology \& Evolution 14:135139.

10. HARMS, V.L. 2003. Checklist of the vascular plants of Saskatchewan and the provincially and nationally rare native plants in Saskatchewan. University Extension Press, Saskatoon, SK.

11. JACOBSEN, S.-E., A. MUJICA, and C.R. JENSEN. 2003. The resistance of Quinoa (Chenopodium quinoa) to adverse abiotic factors. Food Reviews International 19:99-109.

12. KERSHAW, L., J. GOULD, D. JOHNSON, and J. LANCASTER. 2003. Rare vascular plants of Alberta. University of Alberta Press, Edmonton, $A B$.

13. LARCHER, W. 1973. Physiological Plant Ecology. Springer-Verlag, New York.

14. LOOMAN, J., and K.F. BEST. 1979. Budd's Flora of the Canadian Prairie Provinces. Canadian Government Publishing Center, Supply and Services Canada, Hull, QU.

15. MOSS, E.H. 1983. Flora of Alberta $\left(2^{\text {nd }}\right.$ edition by J.G. Packer). University of Toronto Press, Toronto, ON.

16. ROBSON, D.B. 1999. Reasons for prairie plant rarity. In Proc. of the $5^{\text {th }}$ Prairie Conservation and Endangered Species Conference (J. Thorpe, T.A. Steeves, and M. Gollop, eds.). Prov. Museum of Alberta, Edmonton, $A B$.
17. ROBSON, D.B. 2006. Status of smooth goosefoot, Chenopodium subglabrum (Chenopodiaceae) in Canada. Canadian Field Naturalist 120:335-341.

18. ROYER, F., and R. DICKENSON. 1999. Weeds of Canada and the Northern United States. University of Alberta Press and Lone Pine Publishing, Edmonton, AB.

19. SCOGGAN, H.J. 1956. Flora of Manitoba. National Museum of Canada, Ottawa, ON.

20. SMITH, B.D. 1985. The role of Chenopodium as a domesticate in pre-maize garden systems of the eastern United States. Southeastern Archaeology 4:51-72.

21. STOKES, P., and P. ROWLEY-CONWY. 2002. Iron age cultigen? Experimental return rates for fat hen (Chenopodium album). Environmental Archaeology 7:95-100.

22. STUART, M. 1979. The Encyclopaedia of Herbs and Herbalism. Orbis Publishing, London, U.K.

23. VAN WYK, B. 2005. Food Plants of the World. Timber Press. Portland, OR.

24. WELSH, S.L., C.W. CROMPTON, and S.E. CLEMENTS. 2003. Chenopodiaceae. In Flora of North America, volume 4 (Flora of North America Editorial Committee, eds.). Oxford University Press, New York, NY. pp. 258-404.

25. WICKENS, G.E. 2004. Economic Botany: Principles and Practices. Springer, New York, NY.

\section{BEACHCOMBER}

A turnstone overturns beach stones

with crowbar bill his tool to mine

for food. Crustacea he eats

and mollusks small steeped well in brine,

then waddles on on orange legs

along the pebble-strewn shoreline.

- Victor C. Friesen 